\title{
ANALISIS GAUSSIAN DAN EDGE CONNECTION DALAM PENAJAMAN DETEKSI TEPI MENGGUNAKAN METODE CANNY
}

\author{
Kezia Satyawati ${ }^{1}$ \\ keziasatyawati@ti.ukdw.ac.id
}

\author{
Junius Karel Tampubolon ${ }^{2}$ \\ karel@staff.ukdw.ac.id
}

\author{
R. Gunawan Santosa ${ }^{3}$ \\ gunawan@staff.ukdw.ac.id
}

\begin{abstract}
Edge detection is one of many ways to get information from an image without big data storage needed. In this research, the edge detecting is done by implementing Canny edge detection algorithm. The focus of this research is to analyze the effect of two variables of the first process of Canny, Gaussian filter smoothing, that is size of matrix and variance, to the sharpening of edge detection. The testing is done by changing the size of the matrix and the value of the variance. The results showed that the best matrix size and variance for sharp edge detection is less than $30 \times 30$ and 30.
\end{abstract}

Keywords : Gaussian filter, sharpening of edge detection, Canny edge detection

\section{PENDAHULUAN}

Deteksi tepi citra merupakan salah satu cara untuk memeroleh informasi dari citra yang tidak membutuhkan ruang penyimpanan data yang besar. Deteksi tepi citra yang baik adalah deteksi tepi dengan garis yang tidak terlalu tebal, tidak terputus, dan memiliki sedikit noise (Putra,2010)

Beberapa aplikasi atau penerapan deteksi tepi adalah deteksi tumor pada mammogram (Shrivastava,2014), sistem untuk pengenalan iris mata pada manusia ( Singh, 2014), mesin traching untuk batas tepi (Mallareddy, 2014) dan penelusuran papan mesin (Mousa, 2012) .

Banyak penelitian yang telah dilakukan mengenai deteksi tepi citra. Metode yang digunakan pun berbeda-beda mulai dari metode Prewitt, Robert, Sobel, Laplacian of Gaussian, hingga Canny (Dhankhar,2011). Pemilihan metode sangat berpengaruh terhadap hasil akhir deteksi tepi citra karena setiap metode memiliki tingkat akurasi yang berbeda (Jayaraman,2011). Definisi deteksi tepi citra yang akurat menurut pencipta metode deteksi tepi citra Roberts, Lawrence Roberts, adalah mampu menampilkan secara baik tepian citra yang dihasilkan, mampu mengurangi noise sampai sesedikit mungkin, dan intensitas tepi citra yang dihasilkan harus semirip mungkin dengan citra asli (Saluja, 2013).

Pada penelitian ini metode yang digunakan adalah Canny. Alasan dipilihnya metode Canny adalah karena tiga keunggulannya, yaitu mampu menandai sebanyak mungkin tepi asli citra, mampu menempatkan tepi asli yang telah ditandai pada posisi seakurat mungkin sesuai dengan citra asli, dan tepi citra hanya ditandai sekali sehingga noise tidak mempengaruhi tepi yang telah ditandai (Nosrati, 2013).

Faktor-faktor yang diteliti pengaruhnya terhadap ketajaman deteksi tepi dalam penelitian ini adalah dua variabel Gaussian filter, yaitu ukuran matrik dan variansi. Dalam penelitian ini dikembangkan sebuah perangkat lunak menggunakan metode Canny untuk mendeteksi tepi citra dengan variasi pada ukuran matrik dan variansi. Variasi pada ukuran

\footnotetext{
${ }^{1}$ Program Studi Teknik Informatika, Fakultas Teknologi Informasi,Universitas Kristen Duta Wacana ${ }^{2}$ Program Studi Teknik Informatika, Fakultas Teknologi Informasi,Universitas Kristen Duta Wacana ${ }^{3}$ Program Studi Teknik Informatika, Fakultas Teknologi Informasi,Universitas Kristen Duta Wacana
} 
matrik dan variansi diharapkan dapat membantu pengguna untuk menentukan ukuran matrik dan variansi yang terbaik untuk menghasilkan deteksi tepi yang tajam.

Data uji yang digunakan dalam penilitian ini adalah 40 citra, yaitu 10 citra sederhana seperti bangun datar, 10 citra agak kompleks seperti buah apel, logo kendaraan, 10 citra kompleks seperti lukisan abstrak dan pemandangan, dan 10 citra hewan. Citra yang digunakan sebagai data uji berasal dari pencarian search engine Google dan dibuat oleh penulis.

\section{LANDASAN TEORI}

Penelitian dilakukan menggunakan metode Canny. Terdapat lima proses dalam metode Canny, yaitu smoothing dengan Gaussian filter, gradient magnitude, non maxima suppression, double thresholding, dan edge connection/hysteresis. Berikut ini merupakan penjelasan setiap proses.

\subsection{Smoothing dengan Gaussian Filter}

Smoothing merupakan proses penghalusan, dimana pada proses ini dilakukan pengurangan noise yang terdapat pada citra sehingga citra menjadi lebih halus. Dilakukan perkalian antara matrik citra asli dengan matrik kernel Gauss. Matrik kernel Gauss berasal dari penghitungan fungsi Gaussian. Adapun fungsi Gaussian ditunjukkan pada persamaan [1] di bawah ini (Zhou, 2011).

$$
G(x, y)=\frac{1}{2 \pi \sigma^{2}} \exp \left[-\frac{x^{2}+y^{2}}{2 \sigma^{2}}\right]
$$

Berdasarkan persamaan [1] di atas, parameter $\sigma$ merupakan lebar dari Gaussian filter. Semakin besar nilai $\sigma$, semakin lebar frekuensi Gaussian filter. Nilai $\sigma$ dapat disesuaikan berdasarkan citra yang digunakan (Zhou, 2011).

\subsection{Gradient Magnitude}

Proses kedua adalah menghitung gradient magnitude dan arah menggunakan turunan parsial menggunakan operator Sobel. Turunan parsial operator Sobel digambarkan oleh persamaan [3] dan [4] berikut ini (Yuwono,

$$
\begin{array}{r}
s_{x}=\left(a_{2}+c a_{3}+a_{4}\right)-\left(a_{0}+c a_{7}+a_{6}\right) \\
s_{y}=\left(a_{0}+c a_{1}+a_{22}\right)-\left(a_{6}+c a_{5}+a_{4}\right)
\end{array}
$$

Sedangkan gradient magnitude dan arah tepi ditunjukkan oleh persamaan [4] dan [5] berikut ini .$$
M=\sqrt{s_{x}^{2}+s_{y}^{2}}
$$

Langkah selanjutnya adalah men tepi diubah menjadi sudut $45^{\circ}$ yang teraeкат. remoagian arah tepi tersebut ditunjukkan oleh Gambar 1 di bawah ini.
} 


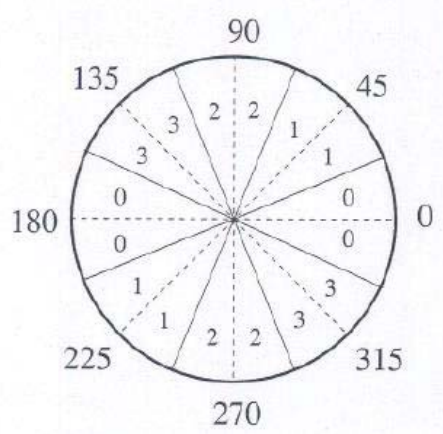

Gambar 1. Pembagian arah tepi menjadi empat sektor

(Saluja, Sonam, Aradhana Kumari Singh, 2013)

Gambar 1 di atas menunjukkan bahwa arah tepi yang berkisar antara 0 dan 22,5 serta 157,5 dan 180 derajat (warna biru) diubah menjadi 0 derajat. Arah tepi yang berkisar antara 22,5 dan 67,5 derajat (warna kuning) diubah menjadi 45 derajat. Arah tepi yang berkisar antara 67,5 dan 112,5 derajat (warna merah) diubah menjadi 90 derajat. Sedangkan arah tepi yang berkisar antara 112,5 dan 157,5 derajat (warna hijau) diubah menjadi 135 derajat.

\subsection{Non Maxima Suppression}

Proses ketiga adalah non maxima suppression, yaitu penghilangan nilai-nilai yang tidak maksimum. Pada proses ini dilakukan perbandingan antara nilai suatu piksel dengan nilai piksel disekitarnya. Apabila nilainya lebih besar maka dipertahankan, apabila lebih kecil maka diubah menjadi nol (Zhou, 2011). Proses tersebut digambarkan oleh Gambar 2 di bawah ini.

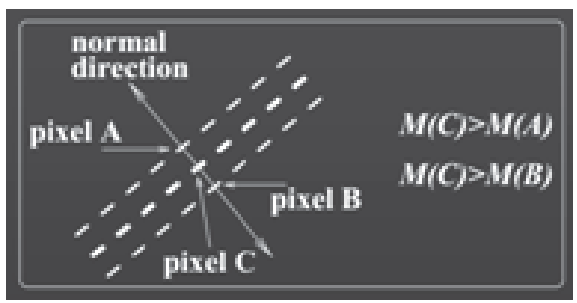

Gambar 2. Ilustrasi non maxima suppression

(Jayaraman, Esakkirajan, Veerakumar, 2011)

Gambar 2 di atas merupakan ilustrasi proses non maxima suppression di mana nilai piksel C dibandingkan dengan piksel A dan B. Jika nilai piksel C lebih kecil dari piksel A dan B, maka diubah menjadi nol. Jika sebaliknya maka nilai piksel C tetap.

\subsection{Non Maxima Suppression}

Proses keempat adalah double thresholding. Setiap tepi dengan nilai yang lebih besar dari threshold tertinggi akan ditandai sebagai nilai tinggi dan tepi dengan nilai yang lebih rendah dari threshold terendah ditandai sebagai nilai rendah. Namun apabila nilanya berada diantara kedua threshold, makaakan dipertimbangkan melalui hubungannya dengan titik disekitarnya (Zhou, 2011).

\subsection{Edge Connection/Hysteresis}

Proses terakhir, yaitu edge connection atau hysteresis adalah penghubungan tepi dengan dua threshold dimana titik dengan nilai kuat akan ditampilkan dalam hasil akhir citra dan titik dengan nilai lemah hanya akan ditampilkan dalam hasil akhir citra jika terhubung dengan titik yang memiliki nilai yang kuat (Zhou, 2011). 


\section{METODOLOGI PENELITIAN}

Jumlah data uji yang digunakan dalam penelitian ini adalah 40 citra yang terdiri dari 10 citra sederhana seperti bangun datar, 10 citra agak kompleks seperti buah-buahan dan logo kendaraan, 10 citra kompleks seperti lukisan abstrak dan pemandangan, dan 10 citra hewan. Citra tersebut berupa citra grayscale dan diubah ukurannya menjadi 200x200 piksel. Kemudian citra dideteksi tepinya sesuai dengan proses-proses metode Canny. Namun terdapat variasi pada proses pertama, yaitu smoothing dengan Gaussian filter. Variasi tersebut terdapat pada dimensi matrik dan variansi yang dapat disesuaikan dengan kebutuhan pengguna.

Setelah sistem yang memuat lima proses pada algoritma Canny tersebut selesai dibuat, maka dilakukan langkah-langkah pengujian sebagai berikut (Rhasmi, 2013) :

-Memasukkan nilai variansi

-Memasukkan ukuran filter Gaussian

-Memilih citra yang akan diuji

-Melakukan proses smoothing dengan filter Gaussian

-Melakukan proses gradient magnitude pada citra tersebut

-Mencari arah tepi

-Melakukan proses non maximum suppression

-Melakukan proses double thresholding

-Melakukan proses edge connection/hysteresis

-Menampilkan citra hasil akhir.

Setelah semua proses tersebut selesai dilakukan terhadap 40 citra yang diuji, kemudian dilihat dan ditampilkan bentuk citra sebelum dan citra sesudah dilakukan deteksi tepi dengan metode Canny. Kesimpulan yang diperoleh belum diukur secara kuantitatif tapi hanya dilihat secara indrawi dengan pandangan dari peneliti, karena pada saat penelitian ini belum menggunakan alat ukur kuantitatif untuk menentukan derajat "kebaikan" dari hasil suatu proses deteksi tepi citra.

\section{HASIL DAN PEMBAHASAN}

Pengguna dapat memasukkan dimensi matrik mulai dari 3x3 sampai dengan 100x100 dan variansi mulai dari 0 sampai dengan 100 . Proses selanjutnya berjalan sesuai dengan ketentuan tanpa terdapat variasi.

Dimensi matrik yang diuji adalah $3 \times 3,30 \times 30,60 \times 60$, dan 100x100. Sedangkan variansi yang diuji adalah 1.96, 10, 20, 30, 40, 50, 60, 70, 80, 90, dan 100. Berdasarkan pengujian yang dilakukan, maka didapatkan beberapa hasil sebagai berikut:

\subsection{Analisis Pengaruh Dimensi Matrik Terhadap Deteksi Tepi Citra}

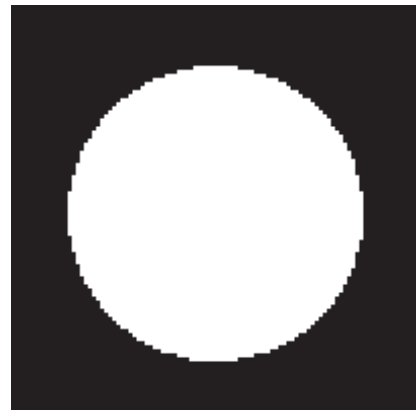

a

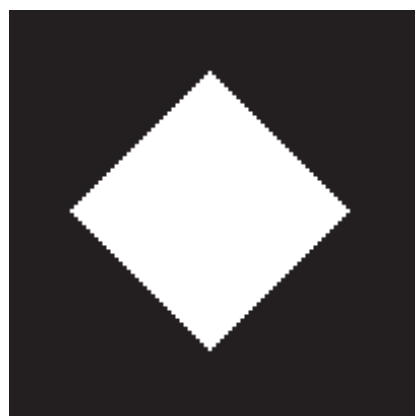

b

Gambar 3. Citra asli 


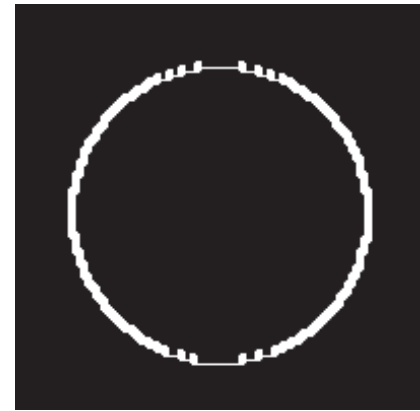

a

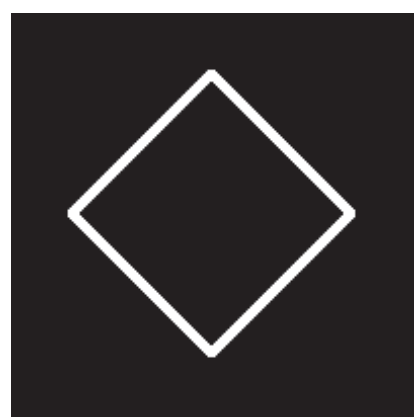

b

Gambar 4. Gaussian filter dengan dimensi matrik 3x3 dan variansi 1.96

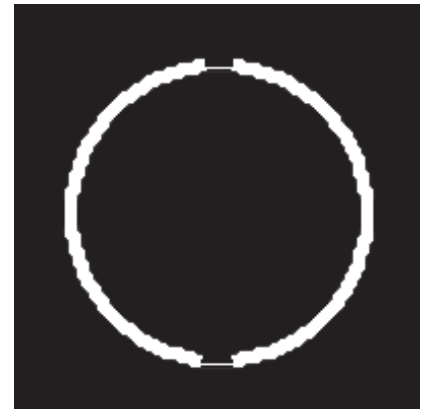

A

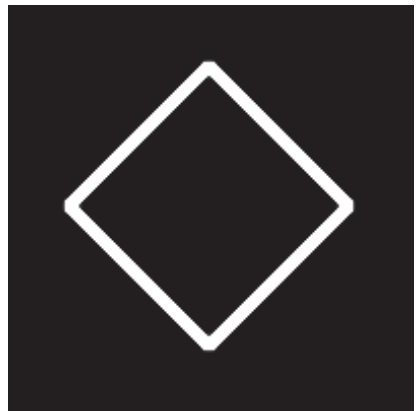

$\mathrm{b}$

Gambar 5. Gaussian filter dengan dimensi matrik 30x30 dan variansi 1.96

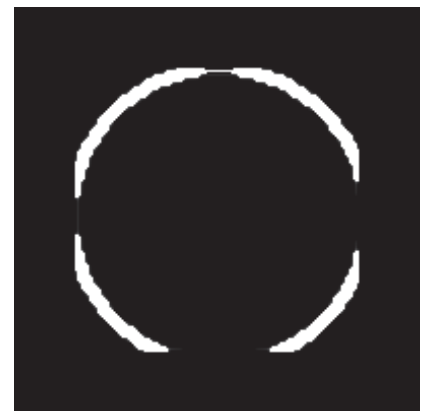

A

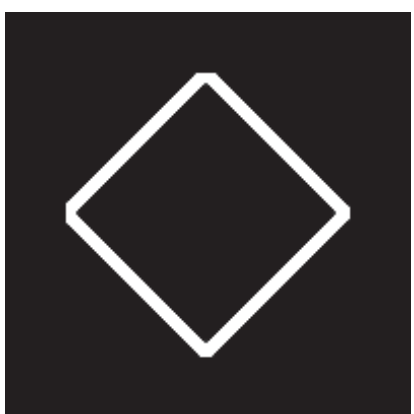

$\mathrm{b}$

Gambar 6. Gaussian filter dengan dimensi matrik 60x60 dan variansi 1.96

Gambar 4, Gambar 5 dan Gambar 6 di atas merupakan deteksi tepi pada citra sederhana. Pada Gambar 4 terlihat bahwa garis tepi lebih tipis apabila dibandingkan dengan Gambar 5 dan Gambar 6. Namun pada Gambar 4 bagian a, terlihat garis tepi bergerigi pada beberapa titik. Sedangkan garis tepi Gambar 5 dan Gambar 6 bagian a tidak bergerigi. Berikut ini merupakan beberapa hasil deteksi tepi citra apel dan telepon. 


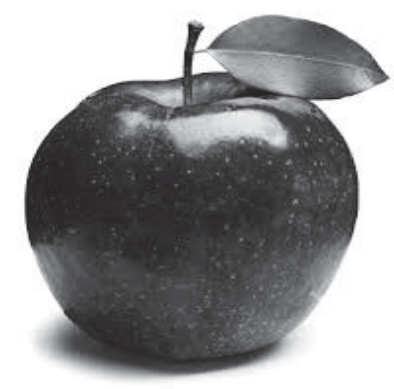

A

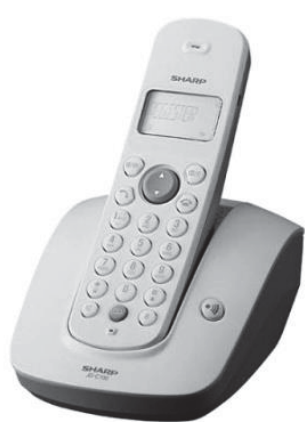

b

Gambar 7. Citra asli

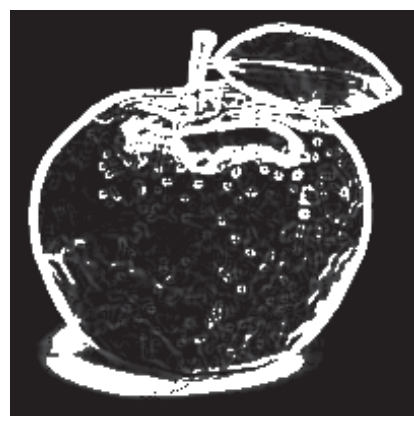

A

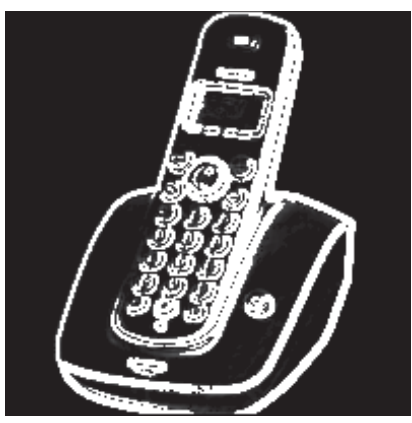

b

Gambar 8. Gaussian filter dengan dimensi matrik 3x3 dan variansi 1.96

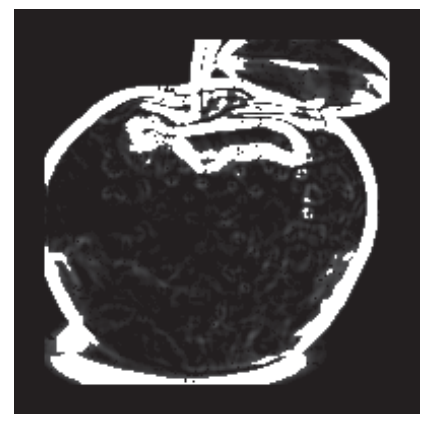

A

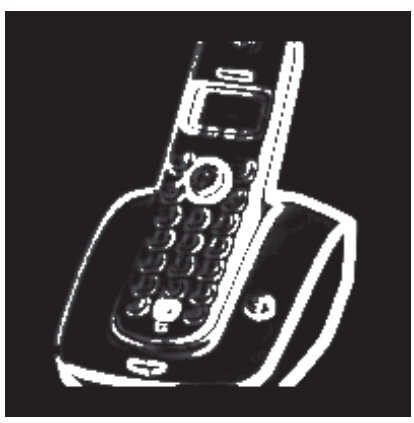

b

Gambar 9. Gaussian filter dengan dimensi matrik 30x30 dan variansi 1.96 


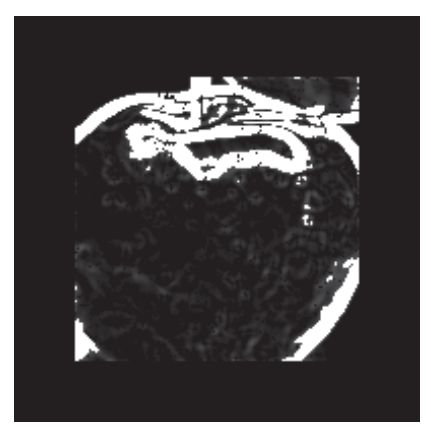

A

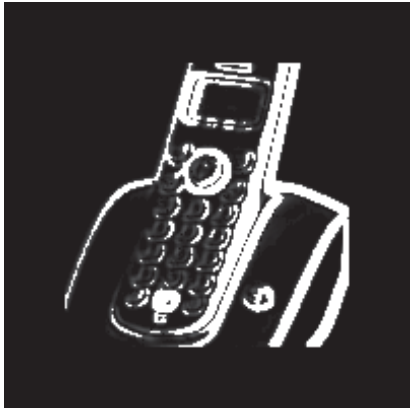

b

Gambar 10. Gaussian filter dengan dimensi matrik 60x60 dan variansi 1.96

Pada Gambar 8 bagian a, terlihat bahwa banyak noise pada permukaan apel yang dianggap sebagai tepi, sedangkan pada Gambar 9 dan Gambar 10 bagian a, noise yang dianggap sebagai tepi tidak sebanyak Gambar 8. Namun Gambar 8 bagian a memiliki hasil deteksi tepi yang tampak lebih tipis dibandingkan dengan Gambar 9 dan Gambar 10 bagian a.

Pada Gambar 8 bagian b, terlihat tepi tombol dan layar telepon. Sedangkan pada Gambar 9 dan Gambar 10 bagian b, hanya sedikit tepi tombol yang terlihat, dan hanya setengah tepi layar telepon yang terlihat. Gambar 8 tampak memiliki hasil deteksi tepi yang lebih tipis dibandingkan dengan hasil deteksi tepi Gambar 9 dan Gambar 10.

\subsection{Analisis Pengaruh Variansi Matrik Terhadap Deteksi Tepi Citra}

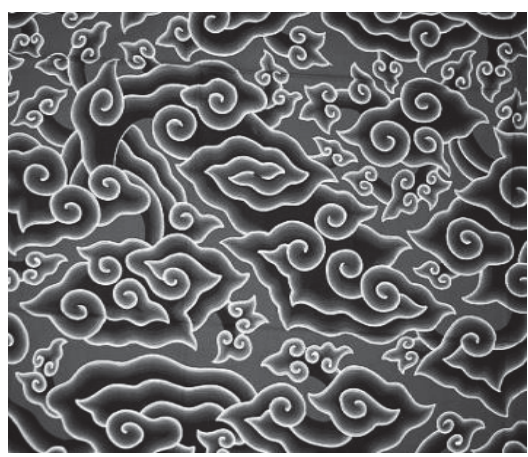

A

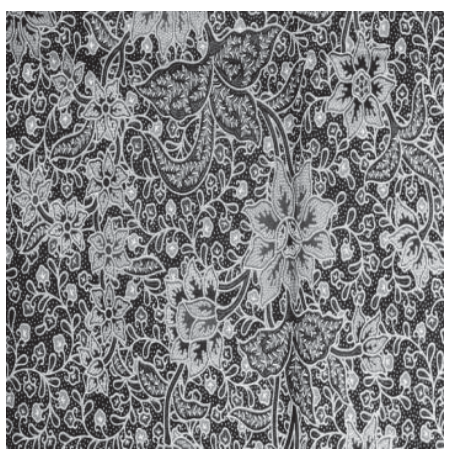

b

Gambar 11. Citra asli
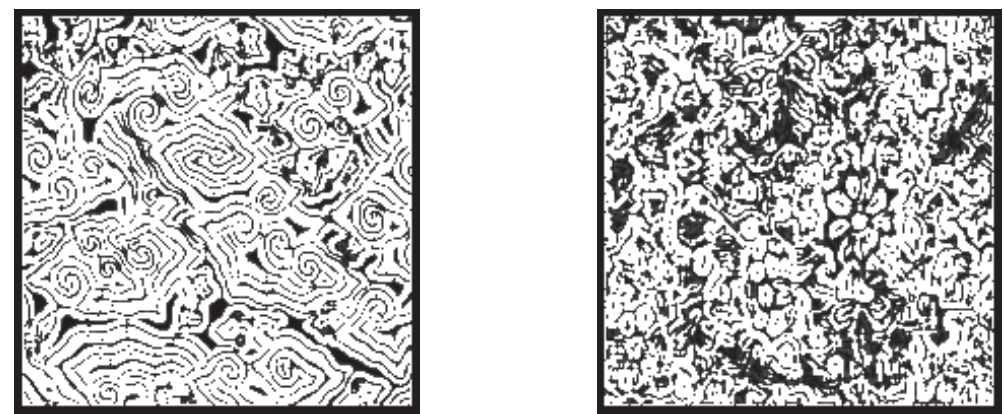
A

b

Gambar 12. Gaussian filter dengan dimensi matrik 9x9 dan variansi 1.96

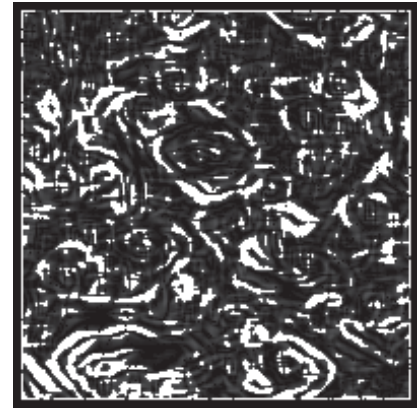

A

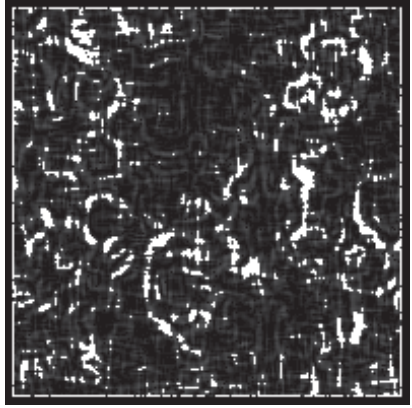

b

Gambar 13. Gaussian filter dengan dimensi matrik 9x9 dan variansi 50

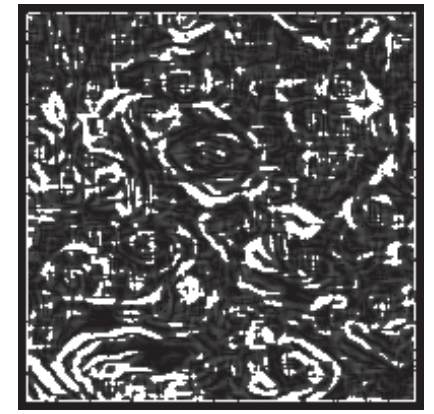

A

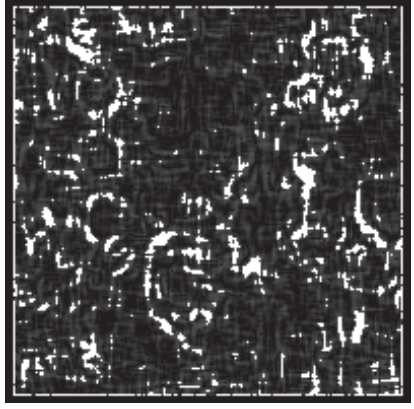

b

Gambar 14. Gaussian filter dengan dimensi matrik 9x9 dan variansi 100

Pada Gambar 12 garis tepi cukup tipis dan terlihat membentuk motif batik. Namun pada Gambar 13 dan Gambar 14 garis tepi terlihat tebal dan samar-samar sehingga motif batik tidak terbentuk. Berikut ini merupakan beberapa hasil deteksi tepi citra lainnya berupa citra hewan.

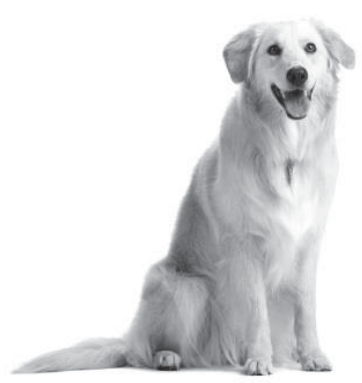

a

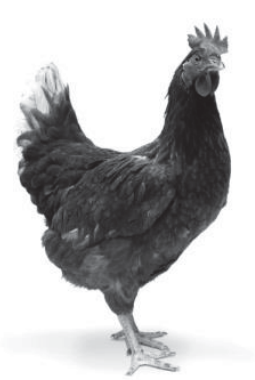

b

Gambar 15. Citra asli 


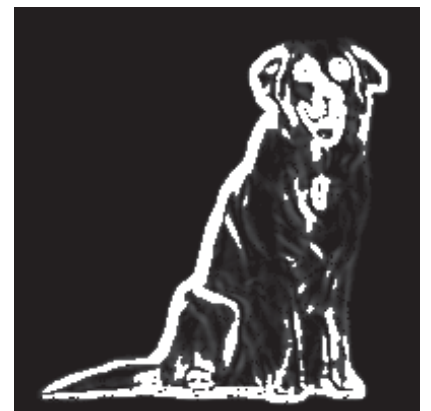

a

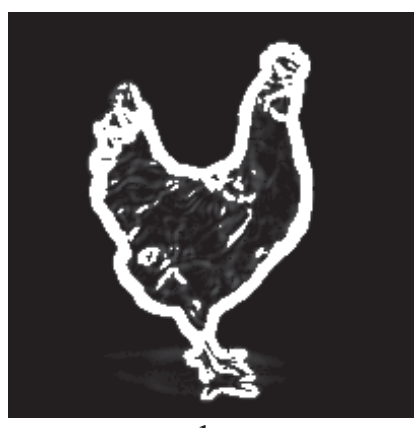

b

Gambar 16. Gaussian filter dengan dimensi matrik 9x9 dan variansi 1.96

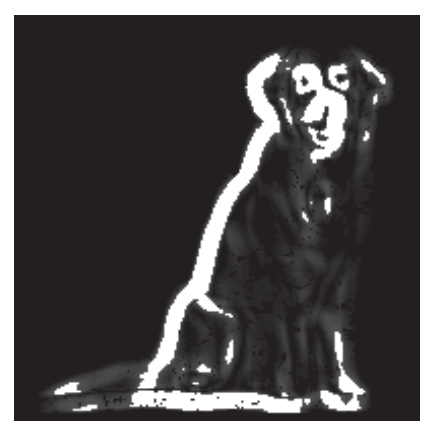

a

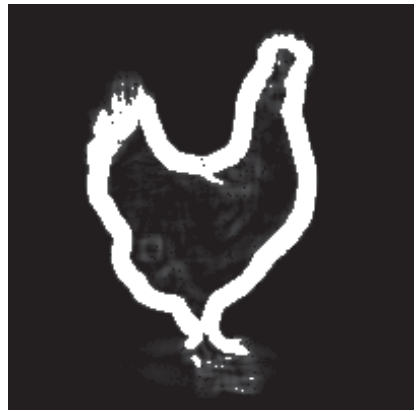

b

Gambar 17. Gaussian filter dengan dimensi matrik 9x9 dan variansi 50

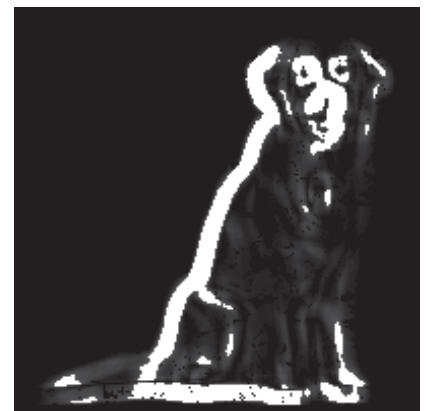

a

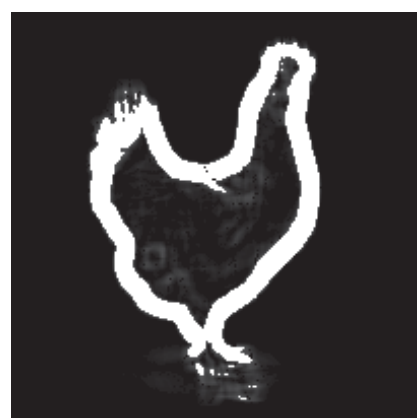

b

Gambar 18. Gaussian filter dengan dimensi matrik 9x9 dan variansi 100

Gambar 16 memiliki garis tepi yang lebih tipis dan lebih banyak mendekati tepi asli citra dibandingkan dengan Gambar 17 dan Gambar 18. Sedangkan Gambar 17 dan Gambar 18 tidak memiliki perbedaan yang mencolok. Namun terlihat perbedaan pada Gambar 16 bagian b, yaitu noise yang lebih sedikit apabila dibandingkan dengan Gambar 17 dan Gambar 18 bagian $b$.

\section{KESIMPULAN}

Berdasarkan penelitian yang telah dilakukan, dapat disimpulkan bahwa dimensi matrik yang kecil menghasilkan garis tepi citra yang tipis, tetapi menghasilkan banyak noise pada citra yang dianggap sebagai tepi. Sedangkan dimensi matrik yang besar menghasilkan garis tepi citra yang lebar, tetapi menghasilkan lebih sedikit noise yang dianggap sebagai tepi. 
Variansi yang kecil menghasilkan garis tepi citra yang tipis dan mampu mendeteksi tepi obyek dengan lebih akurat sehingga tepi yang ditampilkan mendekati tepi asli obyek. Sedangkan variansi yang besar menghasilkan garis tepi citra yang lebar dan menghasilkan berkurangnya tepi obyek yang dideteksi sehingga tepi obyek yang seharusnya ditampilkan menjadi hilang.

Hasil pengujian yang telah dilakukan menunjukkan bahwa ukuran matriks dan nilai variansi yang menghasilkan deteksi tepi citra yang baik adalah kurang dari 30x30 dan variansi dengan nilai kurang dari 30 .

Proses penarikan kesimpulan yang diperoleh belum diukur secara kuantitatif tapi hanya dilihat secara indrawi dengan pandangan dari peneliti, karena pada saat penelitian ini belum menggunakan alat ukur kuantitatif untuk menentukan derajat "kebaikan" dari hasil suatu proses deteksi tepi citra. Sebagai saran untuk penelitian berikutnya adalah mencari alat ukur berupa rumus matematis untuk melihat "tingkat kebaikan" hasil suatu proses deteksi tepi citra.

\section{Daftar Pustaka}

Dhankhar, Poonam, Neha Sahu. A Review and Research of Edge Detection Techniques for Image Segmentation. (2013). Diambil dari:

http://www.ijcsmc.com/docs/papers/July2013/V2I7201329.pdf

Jayaraman. S, S. Esakkirajan, T. Veerakumar. Digital Image Processing. (2011). New Delhi. Tata McGraw Hill Education Private Limited.

Mallareddy, A, R. Chitti Babu, K. Deepika Rani. Vehicle Tracking using Canny Edge Detector. (2014). Diambil dari:

https://internationaljournalofresearch.files.wordpress.com/2014/08/vehicle-tracking-using-canny-edgedetector-by-a-mallareddy-r-chitti-babu-k-deepika-rani.pdf

Mousa, Allam. Canny Edge-Detection Based Vehicle Plate Recognition. (2012). Diambil dari http://www.sersc.org/journals/IJSIP/vol5_no3/1.pdf

Nosrati, Masoud, Ronak Karimi, Mehdi Hariri, Kamran Malekian. Edge Detection Techniques in Processing Digital Images: Investigation of Canny Algorithm and Gabor Method. (2013). Diambil dari: http://www.waprogramming.com/download.php?download=517cbaaeca0d93.40790585.pdf

Putra, Darma. Pengolahan Citra Digital. (2010). Yogyakarta. Penerbit Andi.

Rashmi, Mukesh Kumar, Rohini Saxena. Algorithm and Technique on Various Edge Detection: A Survey. (2013). Diambil dari: http://airccse.org/journal/sipij/papers/4313sipij06.pdf

Saluja, Sonam, Aradhana Kumari Singh, Sonu Agrawal. A Study of Edge-Detection Methods. (2013). Diambil dari:

http://www.ijarcce.com/upload/january/20-A\%20Study\%20of\%20Edge-Detection.pdf

Shrivastava, Pratishta, K.G.Kirar. Detection of Tumor in Mammograms Using Canny Edge Detection Technique. (2014). Diambil dari:

http://www.ijettjournal.org/volume-14/number-5/IJETT-V14P242.pdf

Singh, Naveen, Dilip Gandhi, Krishna Pal Singh. Iris Recognition System Using A Canny Edge Detecion And A Circular Hough Transform. (2011). Diambil dari: http://www.ijaet.org/media/0001/27IRIS-RECOGNITION-SYSTEM-USING-A-CANNY-EDGEDETECTION-AND-A-CIRCULAR-HOUGH-TRANSFORM-Copyright-IJAET.pdf

Singh, Satvir, Arun Kaushik. IRIS Biometric Identification System Based on Modified Canny Edge Detection Algorithm. (2014). Diambil dari:

http://www.ijcat.org/IJCAT-2014/1-4/IRIS-Biometric-Identification-System-Based-on-ModifiedCanny-Edge-Detection-Algorithm.pdf

Yuwono, Bambang. Implementasi Smoothing Menggunakan Mean Filtering, Median Filtering, Modus Filtering dan Gaussian Filtering. (__ $)$. Diambil dari: http://repository.upnyk.ac.id/1979/1/8_BAYU-JURNAL.pdf

Zhou, Ping, Wenjun Ye, Yaojie Xia, Qi Wang. An Improved Canny Algorithm for Edge Detection. (2011). Diambil dari:

http://www.jofcis.com/publishedpapers/2011_7_5_1516_1523.pdf 